DOI: $10.7819 /$ rbgn.v15i48.1503

Subject Area: Organizational Strategy and Behavior

\title{
Challenges and Opportunities in Science Parks' Management: design of a tool based on the analysis of resident companies
}

\author{
Desafios e Oportunidades na Gestão de Parques de Ciência: projeto de uma \\ ferramenta baseada na análise de empresas residentes
}

\section{Retos y Oportunidades en la Gestión de los Parques Científicos: diseño de una herramienta basada en el análisis de las empresas residentes}

\author{
Ana Isabel Jimenez-Zarco ${ }^{1}$ \\ Monica Cerdan-Chiscano ${ }^{2}$ \\ Joan Torrent-Sellens ${ }^{3}$
}

Received on December 6, 2012/ Approved on September 24, 2013

Responsible Editor: João Maurício Gama Boaventura, Dr.

Evaluation Process: Double Blind Review

\begin{abstract}
The correct management of science parks is strategic for universities, as well as a synergistic effect for companies therein installed. Park managers have to decide, among other things, whether they create new academic spin-offs, invest in technology-based companies, or consolidate start-ups already installed in the park once incubation period is complete. These decisions have a direct impact on the university's financial capacity. The quality of decisions taken, as well as their associated risk, will depend on the tools available to park managers. Nevertheless, each
\end{abstract}

park has specific characteristics and situations. Hence, managers need to have tools that adapt to the reality of the park, and which, therefore, contemplate: (1) entrepreneurs' profiles; (2) the nature and behavior of the companies installed in the park; as well as (3), the interrelationships which take place between the different players that make up the park. To have information about the current situation of companies in the park will make the decision-making processes easier for managers. Based on these ideas, this paper seeks to design and test a management tool for science parks. In its design, the tool will consider

1. PhD, Assistant professor, Economics and Business Studies and UOC Business School (UOCBs). Senior Researcher at I2TIC (IN3-UOC). Universitat Oberta de Catalunya (UOC). [ajimenezz@uoc.edu]

2. PhD, PRUAB Marketing and Innovation Manager, Autonomous University of Barcelona. Junior Researcher at I2TIC (IN3-UOC). [monica.cerdan@uab.cat]

3. PhD, Assistant professor, Economics and Business Studies. Director, UOC Business School (UOCBs). Director, I2TIC (IN3-UOC). Universitat Oberta de Catalunya (UOC). [jtorrent@uoc.edu]

Authors' address: Estudios de Economía y Empresa, Universitat Oberta de Catalunya, Avda Tibidabo 39, 08036, Barcelona, Spain Edificio Eureka, Parque Tecnológico de la Universitat Autónoma de Barcelona Edificio Eureka- 08193 Bellaterra (Cerdanyola del Vallès) - Barcelona, Spain 
the previously mentioned criteria. Thus, from the observation and analysis of the companies installed in the park, we seek to identify the factors that affect their growth. Meanwhile, the suitability of the tool was tested at the Autonomous University of Barcelona's Research Park. The analysis of a sample of companies in the park revealed the influence that age, size and type of company financing and the profile of entrepreneurs and their propensity to grow have on the business growth of the companies at the AUB Park. Likewise, we also highlight the usefulness that the tool offers to park managers, as well as its simplicity, flexibility and adaptability for use within the framework of any Science Park model.

Keywords: Academic Spin-offs. Universitycompany transfer. EBC. EBT. Start-up Science Park.

\section{RESUMO}

A gestão de parques de ciência é um fator estratégico para as universidades e tem um efeito sinérgico para as empresas neles instaladas. Os gestores dos parques têm de decidir, entre outras coisas, se incentivam a criação de novas spin-offs acadêmicas, se investem em empresas de tecnologia ou se fortalecem start-ups já instaladas no parque, uma vez terminado o período de incubação. Essas decisóes têm um impacto direto na capacidade de financiamento da universidade. A qualidade das decisóes tomadas, bem como o risco associado, dependerá das ferramentas que estão disponíveis para os gestores do parque. Cada parque, no entanto, possui características e encontra-se em uma situação particular. Por isso, os gestores precisam de ferramentas que se adaptem à realidade do parque, como: (1) o perfil dos empreendedores, (2) a natureza e o comportamento das empresas instaladas no parque, e (3) as inter-relaçôes entre os diferentes atores que fazem parte do parque. Ter informações sobre a situação atual das empresas é imprescindível e facilitará os gestores do parque no processo de tomada de decisão. Com base no exposto, o presente trabalho tem como objetivo projetar e testar uma ferramenta de gestão para parques de ciência. Em seu projeto, a ferramenta considerará os critérios acima. Assim, a partir da observação e análise das empresas localizadas no parque, pretende-se identificar os fatores que afetam seu crescimento. A adequação da ferramenta foi testada no Research Park da UAB. A análise de uma amostra de empresas do parque mostrou que fatores como idade, tamanho e forma de financiamento, junto com o perfil do empreendedor e sua propensão a ter crescimento no negócio, exercem influência na expansão das empresas do parque UAB. Além disso, também pode ser destacada a utilidade que a ferramenta dá aos gestores do parque, bem como sua simplicidade, flexibilidade e adaptabilidade para ser usada com qualquer modelo de parque de ciência. Em uma época caracterizada pela falta de recursos e pela busca de fórmulas institucionais de autofinanciamento, o uso desta ferramenta de gestão pode influenciar positivamente, tornando possível descobrir oportunidades de investimento para os gestores de parques de ciência e universidades.

Palavras-chave: Spin-offs acadêmicas. Transferência universidade-empresa EBC. EBT. Start-up parque de ciência.

\section{RESUMEN}

La gestión de los parques científicos tiene un carácter estratégico para las universidades y un efecto sinérgico para las empresas en ellos instaladas. Los gestores del parque han de decidir, entre otras cosas, si crean nuevas spinoffs académicas, invierten en empresas de base tecnológicas o consolidan las start-ups ya instaladas en el parque, una vez acabado su periodo de incubación. Estas decisiones tienen un impacto directo sobre la capacidad de financiación de la universidad. La calidad de las decisiones tomadas y el riesgo asociado a ellas dependerán de los instrumentos que estén al alcance de los gestores del parque. No obstante, cada parque presenta unas características y situación particular. De ahí que los gestores necesitan disponer de instrumentos que se adecuen a la realidad del parque, y que por tanto contemplen: (1) el 
perfil de los emprendedores, (2) la naturaleza y comportamiento de las empresas instaladas en el parque, así como (3) las interrelaciones que se producen entre los diferentes actores que forman parte del parque. Disponer de información sobre la situación actual de las empresas del parque facilitará a los gestores los procesos de toma de decisión. Partiendo de lo anterior, el presente trabajo diseńa y testa una herramienta de gestión para los parques científicos. En su diseño, la herramienta contemplará los criterios anteriormente citados. Así, a partir de la observación y análisis de las empresas instaladas en el parque, se pretende identificar los factores que inciden sobre su crecimiento. La idoneidad de la herramienta se testó en el Parque de Recerca de la UAB. El análisis de una muestra de empresas del parque evidenció la influencia que los factores edad, dimensión y forma de financiación de la empresa, y por el perfil del emprendedor y su propensión al crecimiento, ejercen sobre el crecimiento de las empresas del parque UAB. Asimismo, también se pone de manifiesto la utilidad que la herramienta ofrece a los gestores del parque, así como su simplicidad, flexibilidad y adaptabilidad para ser usada ante cualquier modelo de parque científico. En un momento caracterizado por la falta de recursos y por la búsqueda de fórmulas de autofinanciación institucional, el uso de esta herramienta de gestión podría influir positivamente en la toma de decisiones, haciendo posible descubrir oportunidades de inversión a los gestores de los parques científicos y las universidades.

Palabras clave: Spin-offs académicas. Transferencia Universidad-empresa EBC. EBT. Start-up parque científico.

\section{INTRODUCTION: THE SHIFT OF PARADIGM WITHIN UNIVERSITIES}

From the last decade on, science parks have been a key component concerning knowledge transfer from universities to companies. In their facilities, new companies (start-ups) are born as fruits of the entrepreneurial spirit of students and individuals, just as science parks have also reached out for other entrepreneurial organizations that are already consolidated and have long been traditional in the marketplace. Thus, university science parks have been converted into the seed for the creation of industrial clusters as well as the drive for territorial activity and development. However, beyond their effect upon the social and economic levels of a region or territory, science parks also have a relevant effect upon the Spanish university environment.

Since 2010, Spanish universities have been severely affected by the economic crisis. The rise in enrolment rates and the harder conditions to get support for study have negatively impacted enrolment figures that were already affected by the country's economic hardships. In addition, cuts on university budgets and a reduction of public investment in $\mathrm{R}+\mathrm{D}+\mathrm{i}$ have slowed down research activity, as well as the sacking of academic staff in training or in an almost stable position.

Facing this situation, knowledge transfer is starting to be seen as something beyond a university's mission. In it, business opportunities and development based on the exploration of research results are considered. University science parks are thus converted into a key component in this process, and their management becomes strategic for universities. In this regard, starting up of academic spin-offs by students and entrepreneurial researchers, or the direct participation of professors in these spin-offs, the investment from the university in the social capital of technology-based spin-offs ${ }^{1}$, or the consolidation of start-ups in parks once the incubation period is over are decisions that have a direct impact upon the university's results. Thus, technologic parks demand special relevance in the contribution to generate resources for academic institutions. In an economic situation where the traditional university model is not feasible, the exploration and marketing of generated knowledge has become a formula that makes selffinancing and sustainability easier for universities. 
The enactment of the Science, Technology and Innovation Bill at the end of 2011, in Spain, was a significant step forward in legislation terms. Thus, differently from the previously applied Organic Bill \#4/2007, current legislation appreciates universities' social and economic relevance, and based on them defines the conditions for the development of a sustainable model for universities. On one hand, more autonomy is granted to science parks by the university, management-wise. Thus, they are converted into institutional agents that, with their own entity and decision-making capacity, compete in the marketplace with the goal to generate economic resources and activity in and for the university. On the other hand, for the first time, they address questions that are key to Spanish universities in terms of transfer and business. The first question refers to the university's capacity to create and take part in technology-based companies. The second deals with improvements in the bill forbidding researchers to develop any business activity along with teaching. And the third question covers the possibility of exploring the scientific know-how that was obtained in fields like Social and Human Sciences ${ }^{2}$.

In managerial and organizational terms, all this means a step forward by establishing procedures to be followed by creating a technologybased company, and by defining the mechanisms and the share of direct participation that professors can have in these companies. However, the university is thus allowed to explore new means of return from research results in Social and Human Sciences, through the possible creation of knowledge-based spin-offs. The university demands a leading role at the social level. This is actively linked with the university's surroundings and adds to value creation and the economic and social development of the territory, by creating qualified jobs and generating new companies.

However, to develop a science park model that, as a tool for transfer, is sustainable in the long term is difficult given the current situation in which they exist. Legislation establishes, as basic conditions, that:
[...] the activity generated by new companies - public or not - by the University resonates favorably in it. Directly, through participation in profits, or indirectly (through highly qualified job opportunities for professors, relationships of researchers with the productive structure etc).

(SPAIN, 2011.)

Thus, the creation and incubation of new companies within the science park is limited. In this way, from the possible academic spin-offs that will be created in the future, only those that are able to generate resources and wealth over time will be of interest to the park. This means that a significant part of business projects that academic staff and researchers may take to park directors may be refused, depending on their economic feasibility and potential. Still, companies that are currently in incubation phase in the park are also affected by the new management model. In this way, once the incubation phase is over, park directors will decide whether the company stays or not in the park. Only companies that are profitable will remain in the park in the start-up regime. Those that are not will be transferred to other institutions or parks.

In both cases, the repercussion of decisions made is high; hence park managers need tools that in a simple and objective way ensure correct decision-making. In order to properly select academic spin-off business projects, it is recommended to have tools that allow a priori: (1) to assess the future feasibility of the spin-off project and, (2) at the next stage, in case of a technology-based company, determine the share the university will hold in it. However, current legislation does not determine which criteria or analysis tool should be used. Finally, each university establishes the criteria and documentation under which decisions will be made.

Lack of consensus around this topic has led academic institutions to different interpretations of the legislation. There seems to be only an 
agreement as to the importance of business plans in deciding to support a company or not. However, this document is nothing more than the entrepreneur's "statement of intentions". Besides, the entrepreneur's ability to carry it out and achieve the expected results will depend largely on the characteristics of his/her surroundings, i.e., the structure, service portfolio and operational methods of the science park ${ }^{2}$.

This lack of criteria can also be observed in decision-making as to companies in the incubation phase at the park. For this reason, making decisions about the park's operational rules, its infrastructure or basic and advanced service portfolio offered to the companies therein not only affects activity in the park but also conditions the activity of companies, their level of profitability and their capacity for future growth.

Given this situation, this paper aims at designing and testing a tool that is capable of facilitating science park management. A tool that is capable of adapting itself to each park's reality and situation, since its design contemplates the characteristics of companies installed in the park and allows for identifying all factors influencing their growth. To this end, having as reference some of the factors proposed by literature as conditions for growth (MARTÍNEZ-RODRÍGUEZ, 2010), we will consider: (1) the profile of entrepreneurs, (2) the nature and behavior of companies installed in the park, as well as (3) interrelationships formed among different players comprising the park.

The suitability of the tool will be tested in the at the Universitat Autónoma de Barcelona's (PRUAB) Research Park, using as reference for the analysis a group of companies in incubation phase. Considering all factors mentioned before, the next step will be to analyze the impact on business volume variation ${ }^{3}$. In this way, we aim to design an analysis tool to facilitate: (1) assessment and valuation of proposals for creating companies within the new legislation on universities, and (2) the management of existing companies in science parks, and the decision-making related to their future once the incubation period is over.
Results achieved demonstrate how certain company, entrepreneur and founding team characteristics affect the business level obtained, conditioning the company's future growth. Still, it would be expected that the importance and relevance of each factor might change according to the science park in which the company is located. However, the proposed tool usefulness is confirmed, as well as the adaptation to the reality of the several existing science parks. This paper ends by signaling implications that the use of this tool is supposed to have, at theoretical and practical levels, on the evolution of the development, decision-making and management processes of science parks.

\section{SCIENCE PARKS IN THE EUROPEAN CONTEXT}

The science park concept first came about at the end of 1950s in US universities. Their introduction in European universities became relevant at the mid 1980s.

A result of universities' initiative to support business activity development, science parks frequently interact with academic and research institutions. The original idea is that these parks provide access of new companies to infrastructure and technologic, logistics and administrative resources - so as to support them in filling a gap in a highly competitive and dynamic market (BERGEK; NORRMAN, 2008; PHAN; SIEGEL; WRIGHT, 2005).

However, as observed by Ratinho and Henriques (2010), the passing of time has brought evolution to park orientation, targets and even the range of resources and services that the parks make available to companies. Thus, the concept of science parks is open to multiple interpretations and subject to changes due to past experiences. Several articles written over time provide different definitions in regard to this concept. However, many of these variations have in common the fact that they point out the interest of parks 
in nurturing regional development, with focus on technology or creating jobs and wellbeing (RATINHO; HENRIQUES, 2010).

Currently, European universities present two main motivations to establish science parks: regional development and creation of synergies (BAKOUROS; MARDAS; VARSEKELIS, 2002). Consequently, the mission for creating parks is expanded. Not only resources and space are provided, but the importance of developing new businesses is emphasized. The creation of young companies within the technology industry is supported, as well as attempts to attract consolidated companies (SCOTT; LINK, 2003). Along with this, local university scholars and researchers are encouraged to commercially explore the results of their research by establishing a relationship between the university and the company (VEDOVELLO, 1997), developing transfer activities (BASILE, 2011) or creating spin-off companies (BOZEMAN; FAY; SLADE, 2013; TARTARI; SALTER; D'ESTE, 2012).

To this end, science parks have developed new management units and implemented supporting programs, such as the creation of company incubators or development of acceleration programs (AERNOUDT, 2004). In this way, companies can access and offer a broad range of specialized consulting, networking, financing and training services etc, at a low cost.

The importance of parks in facilitating companies - inside and outside - the university, and to promote regional development or the creation of synergies, is apparently not always fruitful. Research carried in the 1990s, such as the studies of Massey, Quintas and Wield (1992), point out that the contribution of science parks to the technology transfer process has been relatively low. In line with the above, Westhead and Storey (1995) point out that parks have a negative effect on incubating companies, and that the chances these companies have to survive once the park is created is relatively low. Still, and in relation to the venture and the creation of spin-offs within universities, science parks play at an unleveled ground. Certain authors, such as Tartari, Salter and D'Este (2012) and Basile (2011), point out how parks can slow down university venture processes by increasing paperwork or making result dissemination harder. On the other hand, Gower, Harris and Cooper (1996) indicate how parks ease the interconnection between industry and university, promoting flows of ideas and personnel. More recently, Albahari, Catalano and Landoni (2013) showed how certain parks provide an important contribution to regional development in economic and social terms, by facilitating the development of a specialized, innovative industry, and by creating seeds that foster the cluster.

Albahari, Catalano and Landoni (2013), Phan, Siegel and Wright (2005), and Ratinho and Henriques (2010), amongst others, state that different results obtained by the parks are in line with different characteristics among the parks. Despite the legal, economic and social context being the same, results obtained may vary from one park to another. Previous papers highlight that some elements, such as the strategic orientation followed by the park and the support granted by the university, influence the park management model and, thus, their results.

Apart from the aforementioned elements, however, we considered that the management model applied by parks is also affected by the type and characteristics of the companies within it. The presence of a significant percentage of academic technology-based spin-offs (QUINTASCORREDOIRA et al., 2012), the presence of entrepreneurs with academic backgrounds and high degrees of commitment to their projects (PARKER; PRAAG, 2012), or access to financial resources (LOCKETT; WRIGHT, 2005; TARTARI; SALTER; D'ESTE, 2012), condition not only the park business model but also their activity level and chances of success. 


\section{I Science parks in spain: evolution and current situation}

Over the last decade, Spanish universities placed their bets on creating their own science parks. They are the perfect tool for accomplishing two different, but supplementary goals: to nurture regional economic development by creating innovative companies, and by driving technology dissemination and transfer processes from universities to the corporate mesh (CALVOBABÍO, 2008).

The first science parks appeared in Spain by mid-1980s, following a strategy that attracted high technology companies. The goal was to contribute to economic and corporate growth at the local or regional level, despite different situations, regional contexts and specialization of the corporate arena, location, industries and urban functions (VÁSQUEZ-URRIAGO; BARGEGIL; MODREGO RICO, 2012).

The concept changed in the 1990s and was connected irreversibly to the university, when the first parks appeared within them, while previous parks generated or increased their links with universities (ONDATEGUI, 2001). From 2000, parks drove the promotion of collaboration between several agents, in and outside the parks, for knowledge creation and transfer. The strategy was based on the creation of regional networks for the configuration of regional innovation systems. Science parks have consolidated themselves over the last decade and managed to get evident support from the central government. By the middle of the last decade, there were 25 official parks in operation, all of them members of the Association of Science and Technology Parks in Spain (Asociación de Parques Científicos y Tecnológicos en España, APTE) and located in most autonomous communities.

Today, there are 35 science parks managed by universities. They all provide for development of companies based on scientific and technologic knowledge generated by academic researchers and deliver a key contribution to increasing their competitiveness. The park can host companies with different origins, natures and interests: technology-based, academic spin-offs, knowledgebased companies and start-ups (APTE, 2013).

\subsection{Analysis of the legal aspects of science park management in Spain}

In legal terms, management of a science park is very complex. The general legal benchmark is provided by the Science, Technology and Innovation bill (Ley de Ciencia Tecnología e Innovación, LOMLOU), which was passed by the end of 2011. This legislation allowed each university to determine the system that regulates the activity of the science park, and, thus, its role in the transfer process. The more efficient the system is, the greater the chances that the companies and the park itself will obtain better results. And both the range of services provided by the park to the academic community and the economic return from investments in academic companies are key aspects.

This last source is fundamental due to the fact that the majority of the park income depends on it. However, getting economic returns from academic companies is defined by three factors: (1) legislation determining how universities can create and manage academic spin-offs, (2) the strategy pursued by the park itself, and (3) the autonomy degree that the park has to convert from a business unit to an institutional agent able to generate economic resources and activities to the university.

The legislation in force since $2011^{5}$ stipulates that the university is the engine for fostering knowledge and the country's social and economic development. For this reason, along with basic research, the university must drive the transfer of their research results towards the productive sector in a coordinated fashion and complementary to other agents in the science and technology system. In order to facilitate this transfer, the bill establishes two important lines 
of action: the first is related to the participation of academic staff and the university's own staff in the creation of companies; the second is about the role science parks develop in the company management, as well as their relation and position in the university.

Thus, legal improvements related to the conditions of academic staff and researcher is established, promoting the new company always and when the university joins its creation. As for the science park's role, there are gains in autonomy in relation to the university and it establishes as mission to generate economic resources and activity in and for the university.

\subsection{Parks' challenges as to legislation}

Legislation regulating the park will determine their capacity to make academic research dynamic and catalyst for the market. However, LOMLOU just sketches general lines of operation, leaving for each university to decide for the regulation most suited to their statutes6. In the other hand, the multiple regulations developed do not go deep enough on topics relevant to the park management, such as: (1) definition of criteria to be demanded from new technologyand knowledge-based companies so universities can invest on them and add them to their incubation programs, (2) definition of guidelines on investment criteria in new companies by universities, and (3) the management model to apply to those companies that were created based on the former legislation and are still hosted in the park and in the incubation period.

Currently, science parks have to handle two well different realities and, therefore, develop adhoc operations for each company topology. With regard to projects from creating new companies from the university, the park's management body must consider whether to approve such creation and if they will invest in them and at what level. As for companies in the incubation period, the main concern is to achieve they have a proper growth pace to make them profitable such as that, when the incubation period is over, it can be decided whether the company stays or not in the park, in the start-up regime.

However, despite the established legislation generates a sustainable model in the long run, it lacks the required guidelines and analysis tools for managing the park. The park management needs tools that allow them to make decisions regarding the companies already installed in the park as well as to new spin-off projects that may be submitted. For the latter, it is necessary that the university managers may analyze the opportunity to grant permission to the spin-off creation beforehand and, later, decide on invest in the company if it is a technology-based company. The project approval request has to submit a business plan describing the research results the new company will be based upon and detail the people comprising the company, indicating their professional experience and connection to the university. Such documentation is not enough to allow for an assessment of the project feasibility and chances of future success. Those in charge of the science park need additional tools to facilitate decision making with some success certainty.

To establish a tool for this end is quite complex, given the difficulty to forecast the economy evolution or the progress of the company itself. Still, it is certain that the observation of companies already installed in the park and the detection of these elements affecting the growth of their businesses may be a guide and provide some criteria to make the previous decision making easier. At the end of the day, the companies installed in the park are located in the same environment and under the same circumstances that those which are newly created.

\section{BUILDING A VALUATION TOOL: ANALYSIS OF DETERMINING FACTORS FOR ACADEMIC SPIN-OFF SUCCESS}

To establish standards and determining factors of business growth are classic topics, but 
still very frequent in studies on organizations. Many academic and professional papers have investigated how companies grow. However, there is no consensus given the diversity of empirical results obtained (LEE, 2010).

In many ways, the dispersion found in results can be explained for two reasons. In one hand, this is due to the indicators used to measure business growth. At another, for elements proper and foreign to business organizations, considered as determining for their growth. For the first question, it is important to note that the economic literature proposes different indicators to measure growth. For instance, the work of Fariñas and Moreno (2000) suggest measuring growth as a function of the company's number of employees, such as that if a period longer than one year this number increases, then it is possible to say that the company grew. Martínez-Rodríguez (2010) measure growth through assets and business value obtained by the company.

The last variable has been largely used in the corporate arena to track a company growth. In this regard, concepts such as "gazelle company" are defined based on their business growth above 25 percent for three years in a row (INFORMA $D \& B, 2012)$. For this reason, in this paper we will use the second indicator, as the business level growth positively impacts the number of employees.

On what concerns growth determining factors, some studies under the perspective of the resource and capacity theory point how academic spin-off results depend both on the organization aspects and the environment where it is located (DAVIDSSON; DELMAR; WIKLUND, 2006). Thus, some elements to consider include: organization's characteristics and resources (ROBERTS, 1991; TEECE; PISANO; SHUEN, 1997) and external resources obtained (HELLMANN; PURI, 2002; LOCKETT; WRIGHT; FRANKLIN, 2003), the entrepreneur and his project, as well characteristics of the founding team (SHANE; STUART, 2002).

\section{I The organization`s characteristics}

Among the most highlighted organizational characteristics, we must highlight the company connections or the degree of relationship with the university, the size, age, patent availability and availability of its own and external financing.

\section{I.I The company-university relationship}

Different types of companies coexist within a science park. Sanz (2011) points out that parks have followed a double strategy: hosting existing, mature companies in order to boost competitiveness, and fostering in the university's realm the creation of spin-offs through incubation programs. For the latter, Beraza-Garmendia and Rodríguez-Castellanos (2011) propose the four types of different academic spin-offs: independent, connected, joint venture, and subsidiaries. Belonging to one group or to another not only defines the relationship degree between the company and the university but also indicates the university's interest in join the company's capital and management.

Independent spin-offs have no relationship with the university. This allows entrepreneurs to determine their own management model. But it also implies in limitations related to capital investments, low growth capacity and the company's high vulnerability levels to foreign influences. In connected spin-offs, the university joins the project financing, provides incubation, training and consulting services and even grants exploration licenses. Finally, joint venture and subsidiary spin-offs also have a high connection degree with the university. In the first case, the university only invests technical resources and knowledge. In the second, the university grants an exploration license for the developed technology.

Q1. Does the relationship with the university affect the growth of companies located within the park? 


\section{I.2 Company size and age}

The size and age of a company are seen as elements affecting the company's growth. As for size, there is no consensus on the aspect of the relationship between size and growth.

Mishra (2004) maintains that there is a direct relation between both variables in the software industry in India. But Ciriaci, MoncadaPaternò-Castello and Voigt (2012) and JorgeMoreno, García-Tabuenca and Pablo Martí (2003) find indirect relationships between size and growth for Spanish companies from different industries. Finally, Evans (1987) concludes that the relationship between these variables is not linear; so that SMEs and large companies feature high growth rates whilst mid-sized companies do not.

Martínez-Rodríguez (2010) explains the lack of consensus based on the industry, which the company belongs to, and thus, the ability to adapt and endure that these small companies have. SMEs' flat and flexible structures allow for easily and rapidly adapting to the environment and thus to benefiting from market opportunities. However, small sizes imply in less resource availability and thus more weakness facing environmental threats. On the other hand, Bogliacino (2010). Bogliacino, Piva and Vivarelli (2012), Moncada-Paternò-Castello (2011) indicate that, whilst the company expands, the larger their growth, the higher their spending in $\mathrm{R}+\mathrm{D}+\mathrm{i}$, intensive use of ICT or the possibility of moving their production and internationalize their business activity.

Q2. Does the size of companies located in the park affect their growth?

Still, company age is also seen as a determining factor in the ability to grow. A relation between variables is accepted, but there is no consensus on how it happens. Jovanovic (1982) and Jorge-Moreno, García-Tabuenca and Pablo Martí (2003) indicate that the growth rate of companies is smaller as they get old. Otherwise, Ciriaci, Moncada-Paternò-Castello and Voigt
(2012) indicate that Spanish companies grow faster as the younger they are.

It is certain that a mature company knows the market and its trends and agents. This provides the company with a strong strategic position based on the ability to forecast market movement and even enjoy recognition and reputation between their clients or have close, solid relationships with agents in their near environment within the science park (MARTÍNEZ-CAÑAS; SÁEZMARTÍNEZ; RUÍZ-PALOMINO, 2007). But also Ciriaci, Moncada-Paternò-Castello and Voigt (2012), Calvo (2006) and Ortega-Argilés, Vivarelli and Voigt (2009) indicate that in certain industries, such as high technology, younger companies are the most innovative and applying technology more intensively, thus leading to higher growth rates.

Q3. Does the age of companies located in the park affect their growth?

\section{I.3 Having Patents}

In the university domain, patents protect from copy as they provide protection at the time to explore and market results that the university has obtained through research (FERNÁNDEZLÓPEZ et al., 2009).

To assess the economic value of patents have become extremely important to companies (QUINTAS-CORREDOIRA et al., 2012). Valuating intellectual property rights ease trading and technology licenses, as well as the valuation of projects and companies. For companies intensive in young knowledge, whose intangible assets are mainly patents, they make obtaining financing easier and affect the rescue value in case of failure. The patent value features two components. One is the value of the developed invention and that is protected by the patent and the other is the value of patent itself. The latter constitutes the value increment delivered by the protection provided by the patent, which is above the gains that would be generated by the same invention, if unprotected. 
Based on this, the following question was formulated:

Q4. Does the availability of patents affect the growth of companies located in the park?

\section{3.r.4 Availability of own and foreign financial resources}

Having financial resources is one of the elements that affect whether companies academic or not - will boast high growth rates. Especially for spin-offs, the lack of financing has a direct impact in their capacity to execute their daily activity (BROWN; EARLE; LUP, 2005; PISSARIDES; SINGER; SVEJNAR, 2003). The importance of financial resources increases for smaller, newly created and innovative companies. Furthermore, technology-based companies and academic spin-offs find more difficult to obtain funding, due to the inherent risks of the new technology they develop, limited presence of external relationships and the lack of tangible assets to use as collateral (AGUADO; CONGREGADO; MILLÁN, 2002).

The lack of its own resources forces the entrepreneur to pursue external financing, which may come from public or private sources. A public institution or entity grants public financing. In some territories, support from the Administration to the academic business has been fundamental. By channeling support policies to certain activities considered as strategic, the Administration has created financial instruments supporting the creation of new companies or their internalization, their innovation or renovation of productive processes or investment in new technologies.

Q5. Does the availability of public financing affect growth of the companies located in the park?

As for private financing, Aguado, Congregado y Millán (2002), and Lockett and Wright (2005) indicate that the fact of a spin-off receiving external financing means quality, since it implies that the spin-off has successfully passed by the evaluation of professional investors. Thus, to get financial support from private entities is desirable since it adds credibility, experience in management and networking.

However, few are the spin-offs receiving private financing. Shane and Stuart (2002) consider that such lack of interest from investors is explained by asymmetrical information and the high degree of uncertainty on technology, business and management presented by this type of project that overshadows their perspective of success. This difficulty gets even worse if the company is not of a technological nature. Martínez Pavez (2004) indicated that most of external financing, deriving from risk capital funds, are directed to entrepreneurs on technology. All other newly created companies not based on technology struggle to have access to this source of financing.

Q6. Does the availability of private financing affect the growth of companies in the park?

\subsection{The entrepreneur and his/her project}

The entrepreneur has a critical role in the creation of academic companies in science parks. Nevertheless, whether the entrepreneur has academic background or not seems to have a relevant influence in the creation and operation of an academic spin-off.

Nicolaou and Birley (2003) indicate the importance that the entrepreneur has a professional relationship with the university as a professor and/or as researcher. An academic background affects the time the company waits to launch operations as well as their path over time. There are differences between companies managed by entrepreneurs with academic backgrounds and those managed by a board of directors. For the former, the entrepreneur need to match his/her academic activity with the company job demands more dedication and efforts, once the start-up requires more time to be achieved. When the entrepreneur joins a board of directors, his/her activity is oriented towards consulting. 
Q7. Does the entrepreneur academic background affect the growth of companies located in the park?

In the other hand, it is also stressed the importance of certain socio-demographic and psychological aspects as determining their ability to recognize and develop opportunities and later start a business with some success warranties. In this regard, Ardichvili, Cardozo and Rey (2003), Druilhe and Garnsey (2004), and Parker and Praag (2012), identify the ability of entrepreneurs to manage business growth with two aspects of their demographic profile, such as professional and academic background.

Jo and Lee (1996), and Chandler and Jansen (1992) show how previous experience in boards of directors or those obtained in business processes affect the results obtained. The more the experience more is the information businessmen have on problems and barriers they may find during the company's initial years of operation, in addition to the "know-how" acquired to address them.

Still, the entrepreneur's training level also affects his/her ability to adapt to different activities that the organization demands, and face the risks associated. Parker and Praag, (2012) indicate how an individual's higher educational level also increases the formal knowledge he/she accumulates, as well as the income obtained by the organization. Nevertheless, on what concerns to training, it is necessary to indicate the need for technical education and specialized training in management. Jo and Lee (1996) indicate that knowing the product or service offered is a greater advantage in marketing and are technically superior. However, knowledge and abilities in management are also essential, as they can help to identify business opportunities and establish a proper combination of resources and abilities in the organization in order to develop and explore such opportunity (ARDICHVILI; CARDOZO; REY, 2003; RODEIRO-PAZOS; CALVOBABÍO, 2012).'
Q8. Does the entrepreneur's educational level affect the growth of companies located in the park? Q9. Does the entrepreneur's experience level affect the growth of companies located in the park?

Finally, we noted that some entrepreneurs' personality characteristics are determining for the creation and growth of the company. Among them, literature indicates the following: creativity, intuition or ambition along with ability to control, proclivity to risk and the need for recognition (LEE; TSANG, 2001; RAUCH; FRESE; UTSCH, 2005). In relation to the business, such factors tend to be translated in a positive activity - or inclination - towards the organization's growth. Such behavior type is typical of innovative and technologic companies, since the inherent risk and uncertainty demands an entrepreneur that is creative, adventurous and searching for growth opportunities (BERAZA-GARMENDIA; RODRÍGUEZ-CASTELLANOS, 2011).

Based on the above, we formulate the following investigation question:

$Q$ 10. Does a positive attitude from the entrepreneur towards growth affect growth of companies located in the park?

Beraza-Garmendia and RodríguezCastellanos (2011) indicate how growth-oriented academic spin-offs belong to the technology industry and pursue a solid position in the global market. This makes us think that when the entrepreneur focuses on growth, he/she wishes that their company achieves fast growth in a short period of time and for this reason tries to get external financing to support such growth. The resources pursued may have different nature: monetary, human, knowledge or networking. And, among these main external sources used to obtain resources it is worth to mention the entrepreneur's professional and personal network (CHETTY; CAMPBELL-HUNT, 2003; PARTANEN et al., 2008).

Q11. Does the entrepreneur's pursue of external resources affect growth of companies located in the park? 


\section{$3 \cdot 3$ The founding team}

Hambrick and Mason (1984) and Vohora, Wrigth and Lockett (2004) indicate the relevance of some aspects of the founding team, such as their size and experience, to the quality of business decisions and, ultimately, on the revenue obtained.

In relation to the size of the founding team, Blinder and Morgan (2005), Chalos and Pickard (1985), and Sutter (2005) indicate how it grows, larger is the amount of information that can be processed, more consistent are the decisions made and higher is the revenue. In the other hand, studies as one authored by Amason and Sapienza (1997) indicate how a larger size has no effect or even negatively affect the results. In this line, if the size is large, the social integration level and communication among members are lower and conflicts have a greater probability of arising within the team.

However, higher experience and education levels tend to generate high productivity levels. The Human Capital Theory indicates that those companies relying with experienced management teams with higher education levels in several business areas generate more business outcome (PARKER; PRAAG, 2006). Actually, VendrellHerrero and Ortín-Ángel (2010) indicate how, for those entrepreneurs with previous experience in company creation, the yearly return rate for each additional year of education is among $6.1 \%$ and $7.2 \%$. Finally, Lazear (2005) support the ideas above by showing how in complex environments it is necessary a founding team with varied knowledge. In this regard, academic spin-offs require both technical and managerial knowledge. It turns out that a founding team comprising scholars skilled in several knowledge areas, but also including an experienced manager with knowledge on the environment will affect positively the company's productivity.

Based on this, we ask the following question:

Q12. Does the composition of the founding team affect the growth of companies located in the park?

\section{PROPOSAL OF APPLICATION OF THE TOOL}

The literature review has allowed us to suggest research questions on some factors indicated by the literature as determining business growth. In this second part of this paper, we set out to identify their real impact on companies located in a science park. With this, we aim to establish the foundation of a tool that is useful for park managers when: (1) assessing creation proposals of new academic spin-offs, and (2) manage the diversity of companies that are currently located in science parks.

The exploratory aspect of this paper leads us to adopt as unit of analysis one of the most innovative science parks in Spain, Parc de Recerca de la Universitat Autónoma de Barcelona (PRUAB), and within it, the 30 companies located in it as of the end of 2010.

Information was obtained by means of a survey carried out by the Association of Science and Technology Parks in Spain (Asociación de Parques Cientificos y Tecnológicos de España, APTE) during 2010. The questionnaire was sent online to the company manager. With response rate of 86 percent, 26 companies formed the sample. The survey was carried out in October 2010 (See Table 1).

TABLE 1 - Survey's technical data

\begin{tabular}{ll}
\hline Population & 30 companies located in the PRUAB \\
Sample & 26 companies \\
Interview & Personal \\
Margin of error & $\pm 7.1(\mathrm{p}=\mathrm{q})$ at $95 \%$ reliability level \\
Fieldwork & October 2010 \\
\hline
\end{tabular}

Source: The authors.

\section{I The apte and surveys carried out in the park}

The Association of Science and Technology Parks in Spain (Asociación de Parques Cientificos y Tecnológicos de España, APTE) was founded in 1989 aiming to lead science and technology parks in key components of the Spanish innovation system. For this, APTE articulates around 
three networks, the first gathering Science and Technology Park directors; the second works with park technology transfer technicians and their companies. Finally, the third network, and another network, managed by APTE's OTRI that aims to bring the scientific world outside and inside parks with the park corporate arena and working closely with park technicians.

It currently brings together 76 science and technology parks in Spain, 48 as members and 28 as affiliates. By the end of 2011, the number of companies and institutions located in APTE's science and technology parks was 6,030. Most represented industries are ICT, 23\%; and Engineering and Consulting, 14\%. Industries as Health and Biohealth, Industry, Training and Human Resource represent 6\%, 5\% and 4\%, respectively. There were 154,187 employees at the end of 2011, a 6\% growth in relation to 2010 . Some 50 percent of these workers have attended college.

APTE's strategic plan defined as priority to identify the main challenges that science and technology parks in the association will face in the coming years. Get to know the situation and evolution of companies installed in these parks is critical to reach such goal. For this reason it collects data on these companies through surveys. This process is based by the Spanish Science and Technology Foundation (Fundación Española para la Ciencia y la Tecnología, FECYT), which is subordinated to the Ministry of Science and Innovation, support initiatives.

The questionnaire is sent online to the science park managers to distribute among companies located in there. It is carried out in October/November every year. It has not changed over time, so that it allows for comparison of the information obtained from a company over time and then the assessment their evolution. In order to ensure quality of the process, APTE executes later an oversight process through personal interviews with the company. The quantitative information obtained references basic business growth indicators: company's revenue, number of employees, patents and investment in $\mathrm{R}+\mathrm{D}$.

\subsection{The case study: pruab}

Established as a non-profitable, private foundation by the end of 2007, PRUAB is the critical axle through which three leading research entities operate: Universidad Autónoma de Barcelona (UAB), Consejo Superior de Investigaciones Cientificas (CSIC), and Institut de Recerca i Tecnología Agroalimentàries (IRTA). The goal is to improve knowledge and technology transfer between university and company.

The Research Park (UAB) is positioned as an instrument that facilitates the transference of knowledge originated within the university. Currently, the PRUAB has over thirty research centers. Specifically, there are two centers in environmental sciences, ten in social sciences, five in biotechnology and biomedicine, three in animal health and alimentary technologies and fourteen in experimental sciences and technology. Entrepreneurship is developed by nearly fifty companies (between spin-offs and start-ups) of which over $65 \%$ belong to the technology sector.

One of the main activities of the UAB Research Park is the creation of companies as one of their main ways to transfer knowledge to society and to create new openings for qualified students. Finally, note that since 2012, due to the current economic crisis and in order to create economic activity and jobs, the PRUAB opens a line of support for all researchers interested in starting a business project of their own in social field committed to knowledge transfer through collaborative projects with external entities in the fields of Social Sciences and Humanities.

\section{$4 \cdot 3$ Study variables}

Frame 1 lists the variables used in the study. It should be noted that an important part of the variables used in this work have been transformed from continuous metric measurement scales to 
dichotomous scale categories. Despite the loss of information that this process means, it is highly recommended when the sample has a small size. The use of dichotomous scales reduces scattering of information and helps obtain more robust data.

The growth variable will act as the dependent variable of the study. The same is true to the increase of the turnover achieved by the company during the last year of activity. The use of a time horizon of one year, in relation to the growth of turnover, is justified by the fact that an important part of the analyzed companies are in the incubation period and therefore have less than 3 years old.

With regard to the independent variables of the study, as noted, with the variables identified in the previous sections, we have included two dummy variables relating to the sector of activity in which the spin-off operates. In regard to the founding team, we have considered its multidimensional nature, the existence of a scientific team that acts as a consultant to it, and the inclusion of entrepreneur in the founding team. To this end, are included in the analysis three dichotomous variables.

With regard to the profile of the entrepreneur, there have been introduced three additional profile dummy variables: non-academic, unconsolidated academic, and consolidated academic. The difference between them is established considering that the entrepreneur develop a teaching and/or research activity at the university. If so, the difference between non-consolidated and consolidated profile will be marked by the years of experience that the entrepreneur has in the workplace. We understand that an unconsolidated academic profile corresponds to a person with little teaching or research experience, which is in an early stage of their academic career and probably is in development phase of the doctoral thesis, or is it a recent Ph.D. By contrast, a consolidated academic profile corresponds to a person with a solid career in academia. To a highly qualified researcher with prestige, who has great experience in research project management, and thus in the development of outreach and transfer activities. Considering the type of contractual relationship between the entrepreneur and the university, it should be noted that an unconsolidated academic corresponds to a scholarship holder, hired not doctor professor and hired doctor professor. The consolidated academic profile corresponds to the figures of university professor and university lecturer.

The variable relationship between the company and the university has been transformed to use a dichotomous scale. Originally, the variable was measured in the APTE questionnaire considering the type of relationship the company has with the university. Thus, it was felt that this relationship was more or less intense considering that the university owns the company in financial terms, receive training and advice, or has licenses to use patents. This variable does not contemplate the employment relationship between the entrepreneur and the university.

Finally, note that a metric scale measures the questionnaire variables related to public and private funding. However, to simplify the analysis and prevent loss of information involving a wide spread of values, we proceeded to recode the variables. After calculating the mean value of the obtained financing (equal to 100,000 euros), we proceed to classify the different cases depending on whether they had received funding, and if it was above or below the mean value calculated. 


\begin{tabular}{|c|c|}
\hline Variable & Definition \\
\hline Growth & $\begin{array}{l}\text { The company has increased its turnover in the last year. The variable takes the value } 0 \text { if negative, } 1 \\
\text { if positive }\end{array}$ \\
\hline ICT Companies & The spin-off operating in the ICT sector. The variable takes the value 0 if negative, 1 if positive. \\
\hline Bio-sanitary sector companies & The spin-off operating in the ICT sector. The variable takes the value 0 if negative, 1 if positive. \\
\hline Linking to the university & $\begin{array}{l}\text { The company has a relationship with the university. The origin variable takes the value } 0 \text { if not, and } \\
\text { the value } 1 \text { if positive }\end{array}$ \\
\hline Variation in the company size & $\begin{array}{l}\text { The company has changed its size, as measured in number of employees since its inception. The } \\
\text { variable takes the value } 0 \text { if the number of workers has not changed, the value } 1 \text { if the number of } \\
\text { workers has increased less than } 25 \% \text {, and } 2 \text { if the increase is greater than } 25 \%\end{array}$ \\
\hline Company age & $\begin{array}{l}\text { Years of life of the company. The variable takes the value } 0 \text { if it's less than three years, and the value } 1 \\
\text { if it's more than three years. }\end{array}$ \\
\hline Patents & The company has patents. The variable takes the value 0 if not, and the value 1 if positive. \\
\hline Public financing & $\begin{array}{l}\text { The company has managed to obtain public funding for the development of a project. The variable } \\
\text { takes the value } 0 \text { if not, and the value } 1 \text { if the funding has been low (less than 100,000 euros), and } 1 \\
\text { if the financing was high (over 100,000 euros) }\end{array}$ \\
\hline Private financing & $\begin{array}{l}\text { The company has managed to obtain private funding for the development of a project. The variable } \\
\text { takes the value } 0 \text { if not, and the value } 1 \text { if the funding has been low (less than 100,000 euros), and } 1 \\
\text { if the financing was high (over 100,000 euros) }\end{array}$ \\
\hline $\begin{array}{l}\text { Non-academic profile of the } \\
\text { entrepreneur }\end{array}$ & $\begin{array}{l}\text { The driving force behind the project is not an academic or a researcher at the university. The value } 0 \\
\text { indicates that the individual has academic profile, and the value } 1 \text { that the individual is not a univer- } \\
\text { sity academic. }\end{array}$ \\
\hline Unconsolidated academic profile & $\begin{array}{l}\text { The driving force behind the project is an academic or a researcher at the university with few years of } \\
\text { experience in the workplace. The value } 0 \text { indicates that the individual doesn't have this profile, and } \\
\text { the value } 1 \text { indicates that it does }\end{array}$ \\
\hline Consolidated academic profile & $\begin{array}{l}\text { The driving force behind the project is an academic or a researcher at the university with prestige and } \\
\text { a long time of experience in the workplace. The value } 0 \text { indicates that the individual doesn't have this } \\
\text { profile, and the value } 1 \text { indicates that it does }\end{array}$ \\
\hline Formation of the entrepreneur & $\begin{array}{l}\text { Academic level of the entrepreneur. The variable takes the value } 0 \text { when the individual has university } \\
\text { degree, and the value } 1 \text { when a doctor. }\end{array}$ \\
\hline Previous experience & $\begin{array}{l}\text { The entrepreneur has previous experience in the field of the company, having previously developed } \\
\text { some activity in some other company, or have been previously entrepreneur in the company field. } \\
\text { The variable takes the value } 0 \text { if not, and the value } 1 \text { if positive. }\end{array}$ \\
\hline $\begin{array}{l}\text { Willingness of the entrepreneur } \\
\text { to grow }\end{array}$ & $\begin{array}{l}\text { The entrepreneur demonstrates a high interest in the company to grow in terms of turnover, or size. } \\
\text { The variable takes the value } 0 \text { if not, and the value } 1 \text { if positive }\end{array}$ \\
\hline Search for external resources & $\begin{array}{l}\text { The entrepreneur intensely sought external resources (of a financial nature human or technological) } \\
\text { to promote rapid growth of the company. The variable takes the value } 0 \text { if not, and the value } 1 \text { if } \\
\text { positive }\end{array}$ \\
\hline Founding team & $\begin{array}{l}\text { Composition and varied nature of the Members of the founding team. Type founding team of the } \\
\text { company. The variable takes the value } 0 \text { if the team is multidisciplinary and the value } 1 \text { if it's not. }\end{array}$ \\
\hline $\begin{array}{l}\text { Scientific Committee on the } \\
\text { project }\end{array}$ & $\begin{array}{l}\text { Existence of a scientific committee linked to the project. The variable takes the value } 0 \text { if negative, } 1 \\
\text { if positive }\end{array}$ \\
\hline $\begin{array}{l}\text { Entrepreneur joined to the } \\
\text { project }\end{array}$ & The entrepreneur is part of the founding team. The variable takes the value 0 if negative, 1 if positive \\
\hline
\end{tabular}

CHART 1 - Variables used in the study

Source: The authors. 


\section{DATA ANALYSIS}

We begin the next section, characterizing companies settled in the PRUAB, then we'll move to analyze the impact of their characteristics on the level of growth achieved in the last year.

Finally note that this work is eminently exploratory. Thus, the small sample size and membership in a single institution, makes it advisable to analyze the data using non-parametric statistical techniques.

\section{I Characterization of PRUAB companies}

A total of 26 companies were analyzed all of which installed in the UAB Research Park in late 2010 . Of the companies, $77 \%$ are academic spin-offs, and $23 \%$ are start-ups. By sector, a total of 14 companies ( $54 \%$ of the sample) belong to the ICT sector, while the remaining $46 \%$ belongs to the Biosanitary industry. Note that, within specialized ICT companies, $71 \%$ are spin-offs, while for the Biosanitary this percentage increases to $83 \%$.

$38.5 \%$ of companies have less than three years, so they are still in incubation phase. Of the remainder, $30.8 \%$ are between 4 and 6 years, and $30.7 \%$ between 7 and 10 years. Depending on the type of business, we found that among those in the incubation period, $40 \%$ are spin-offs, and $60 \%$ start-ups. These percentages tend to reverse, so that the percentage of spin-offs increases in older companies. Specifically, for those who are between 4 and 6 years, this value reached $87.5 \%$. Whereas it stood at $100 \%$ when companies have between 7 and 10 years. By sector of activity, there are not significant differences depending on the age of the company. Thus, regardless of the age group in which the organization is, the distribution between ICT companies and Biosanitary sector is equivalent and is around $50 \%$.

The $77 \%$ of the PRUAB companies are micro-companies, with less than 6 workers, no significant differences in terms of their size, if we consider the type of business or sector in which they operate. Most of the turnover obtained is low. In $73.5 \%$, companies reported not having exceeded 425,000 euros over the last year. By type of company, $68 \%$ of them are spin-offs, and no important differences appear in their response to billing depending on the activity sector. However, the activity sector turns out to be important in the explaining of the patent availability. Thus, 55.6\% of the companies have a patent, of these $90 \%$ are in the biosanitary industry.

Slightly less than half of companies report having received some funding, both public (46.2) and private $(42.3 \%)$. By type of company, note that the spin-offs have received $100 \%$ of private funding, and $90 \%$ public funding. While, by sector shows how the $68 \%$ of public funding is received by biomedical companies.

To a large extent, obtaining funding depends on the motivation of the entrepreneur, or the founding team, to grow and seek outside resources. In $100 \%$ of cases in which companies obtain financing, the entrepreneur showed interest in growth and found resources for it. However, not all the entrepreneurs have interest in growing. In $38.5 \%$ of cases the entrepreneur says he has no interest in growing, and 34.5\% have not look for the resources.

This is an entrepreneur who is mainly male (96\%), between 30 and 45 years old (53.8 $\%)$, not a doctor (53.8\%), and with no previous experience in the field of business $(61.5 \%)$. In $74.6 \%$ of cases, the entrepreneur has an academic profile but mostly unconsolidated. In $96.5 \%$ of cases the entrepreneur has joined the project. In order to understand the impact of these variables, we proceeded to use the Mann-Whitney statistic method. The small sample size and ordinal nature of the scales used, makes it advisable to use nonparametric statistical techniques. Among them, statistical Mann-Whitney and Kruskal-Wallis analysis are equivalent to the ANOVA analysis. In particular, the Mann-Whitney statistic is suitable for variable sample with different sizes and with less than 30 individuals. This technique makes it possible to test if two independent random samples come from the same business population as part of the multidisciplinary management team.

Finally note that the profile of the entrepreneur does not show significant differences 
by type of business or industry. Just to note that $90 \%$ of start-ups is a not-academic entrepreneur, and that $77 \%$ of bio-sanitary companies is a consolidated academic entrepreneur.

\subsection{Analysis of effect of business characteristics and the entrepreneur in the obtained on growth}

The aim of this section is to determine whether certain characteristics of the firm, the entrepreneur and/or the founding team have effects on the company growth. And $73 \%$ of companies of the PRUAB said that over the last year their turnover has not grown at all.

In order to understand the impact of these variables we statistically proceeded using the Mann-Whitney U. The small sample size and ordinal nature of the scales used makes it advisable to use non-parametric statistical techniques.
Among them, statistical Mann-Whitney and Kruskal-Wallis analysis are equivalent to the ANOVA analysis. In particular, the Mann -Whitney statistic is suitable for variable sample with different sizes and with less than 30 individuals. This technique makes it possible to test if two independent random samples come from the same population.

Table 2 gives the statistics for each of the analyzed variables. The results show how the founding team, the willingness of the entrepreneur to grow and seek for external resources, the variation in the size of the company, age and obtaining private funding affect the growth of the company. All variables are significant at the $99 \%$ and $97 \%$ level of confidence, so that we can reject the null hypothesis of equal samples, and consider that a change in any of the above variables influences the turnover obtained. 


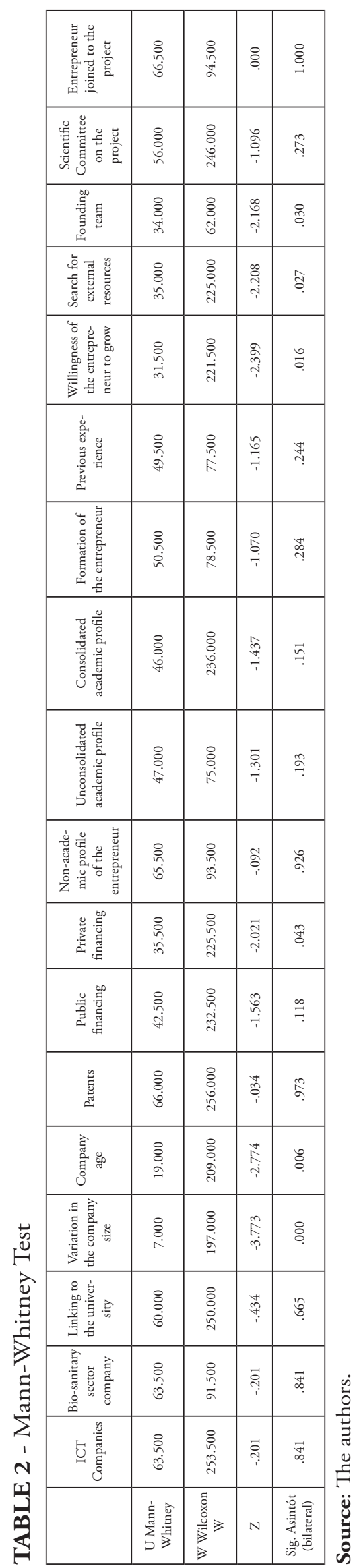


Amongst variables above, the variation in the size of the company, alongside age, are those that have a greater impact on turnover. Whereas with regard to the characteristics of the entrepreneur, is the willingness to grow that produces a more positive impact, followed by the external resources pursue. Finally, the existence of a founding team and obtaining private funding are those that have a lower impact on the growth of the company.

On the other hand, it is interesting to note how the sector of activity in which the company competes, its connection to the university, the availability of patents or the public funding have no influence on the growth of the company. Also, characteristics of the entrepreneur, as its academic profile, training and previous experience in the field of business, or membership in the management team of the company, are not significant in the analysis.

In this way we confirmed the effect of the above variables. The questions of Q2, Q3, Q6, Q10, Q11 and Q12 have a positive answer. Chart 2 shows a summary of the research questions asked and the result obtained.

\begin{tabular}{|c|c|}
\hline Research questions & Answer \\
\hline Q1. Does it affect the degree of linkage with the university in the growth of companies located in the park? & NO \\
\hline Q2. Does it affect in its growth, the size of the companies located in the park? & YES \\
\hline Q3. Does the age of the companies in the park affect its growth? & YES \\
\hline Q4. Does it affect the availability of patents in the growth of companies located in the park? & NO \\
\hline Q5. Does it affect the availability of public funding in the growth of companies located in the park? & NO \\
\hline Q6. Does it affect the availability of private finance in the growth of companies located in the park? & YES \\
\hline Q7. Does it affect the academic profile of the entrepreneur in the growth of the companies located in the park? & NO \\
\hline Q8. Does it affect the amount of training presented by the entrepreneur in the growth of the companies in the park? & NO \\
\hline Q9. Does it affect the level of experience of the entrepreneur in the growth of companies located in the park? & NO \\
\hline Q10 Does a positive attitude towards growth by the entrepreneur affects the growth of companies located in the park? & YES \\
\hline Q11. Does the interest of the entrepreneur to seek external resources affect the growth of companies located in the park?? & YES \\
\hline Q12. Does it affect the composition of the founding team in growing companies in the park? & YES \\
\hline
\end{tabular}

CHART 2 - Summary of the research questions answers

Source: The authors.

\section{INITIAL FINDINGS REGARDING THE PROPOSED TOOL FOR ANALYSIS AND MANAGEMENT OF TECHNOLOGICAL PARKS}

The complex reality of the science park makes it necessary to have the tools to facilitate decision-making. For new business ventures of academic spin-offs, it improves the evaluation and assessment of economic viability, and facilitates the decision to invest in them in case of EBTs. While, in relation to companies already established in the park, makes easier its current management and decision-making regarding their future, once finished its incubation phase.

The detection and analysis of the factors influencing the growth of companies already established in the science park can be useful in this task. The specialized literature recognizes that there are some factors that generally influence the increase in the turnover. However, the environment in which the companies are - defined by the scientific park - defines its effect. Hence, knowing what influences and how they influence 
the growth of companies in each science park may be of interest to (1) assess the feasibility of new business projects that come to him and (2) make decisions regarding the future of the companies already installed.

Based on this idea, this paper proposes the design and construction of analysis and management tools that is available to the managers of science parks. The literature review allowed to identified some features concerning the organization of the entrepreneur and the founding team - if any - that could have an impact on the growth of companies installed in a science park. Subsequently, with the intention to explore its utility, we proceeded to perform a first test on the population of companies in the UAB Research Park. For his extensive experience and innovative orientation, the PRUAB is a reference to implement the study.

The results obtained for PRUAB companies reveal that the variables that are most important for the growth of the company are company size and age. It is expected that a small company be provided with a higher and faster capacity to adapt to the changing environment. However, the benefits offered to have a flat and flexible structure contrasts to the risks of the small size. So, as a company has larger size, disposes of: (1) a greater ability to absorb knowledge, (2) an increased availability of resources -financial and personal-for market analysis and development of $\mathrm{R}+\mathrm{D}+\mathrm{i},(3)$ a greater ability to protect and exploit their inventions through patents and exploitation rights, and (4) do not suffer overflow knowledge processes (knowledge spillovers).

A larger dimension offers greater resilience to the threats of the environment. Just as older age brings with greater experience and degree of market knowledge, trends and agents that comprise it. This will lay the foundations to provide competitive advantages based on social capital, reputation and experience of the company.

The entrepreneur also has a strong influence on the growth of the company. In particular, the willingness to grow and resources pursue are the related variables that have influence on the turnover obtained. Consistent with the findings obtained in different studies, the entrepreneur has some psycho-sociological traits that predispose the constant goal setting, the taste for risk, or the need for improvement. This suggests that an entrepreneur by nature seeks the growth of the organization.

However, the propensity for entrepreneurial growth is conditioned by life cycle phase in which the organization stands, as well as the characteristics of the environment. Clearly, when the company is in an early stage of its life cycle needs to grow to achieve a suitable size within the market to become profitable. But the moment will come when the entrepreneur/ businessman decide whether to grow or not, depending on the environment. Sometimes increasing the volume of activity, or seek new markets is not convenient, as it may require resources that result in a loss of control that the entrepreneur cannot or do not want to assume.

What is clear is that an entrepreneur that tends to growth is more likely to seek for external resources. In fact, the very presence in the science park is already justified by it. Resources to search can be human and technological as well as financial. The search for knowledge, technology or human and social capital leads the entrepreneur to make use of, among others, their social and professional networks, which, as has been pointed out, have a major impact on different types of company outcomes.

According to the search of external financial resources, the results obtained in this paper show how companies that have external funding have experienced a growth in the turnover of the last year. According to previous works such as Aguado, Banded and Millan (2002), Lockett and Wright (2005), or Rodeiro-Pazos and Babío Bald (2012), financial support of private investment entities is desirable because it adds credibility, management experience and networks of relationships, even more, when in practice, 
are few companies arising from university who receives it.

Finally, have a founding team influences the results obtained. This result is consistent with those obtained in previous studies, and shows how the presence of an experienced management team has a positive impact on the management of the organization, being larger the informational burden that can be processed and more consistent the decisions made. And is that, the more experience and training, the higher the ability to respond quickly and successfully to complex situations, tending to generate higher levels of productivity and competitiveness.

\section{PROS AND CONS OF THE PROPOSAL: FURTHER CHALLENGES TO ACHIEVE}

We have already pointed out that the aim of this paper is to propose a tool that encourages the management of science parks in the field of spin-offs and academic EBT, given the complex situation in which they are currently found.

It is obvious that the study of a small sample of companies, and located in a specific science park, makes that the paper presents important limitations. These include the fact that a $38 \%$ of companies are in the incubation phase, which implies the use of a very short time horizon for analysis of the dependent variable, or that a small percentage of companies (27\%) have shown positive growth during the last year.

However, we believe that the proposal of a tool with these features can be useful to managers of science parks, since it allows to:

Adapt it to the reality of each science park. It is possible to have an ad hoc tool for the science park, to be able to consider the number and type of variables that managers see fit.

(1) It is based on a simple and easy to interpret analysis, but that it can also be adapted to the reality of the park. The study of large samples and variables measured in metric scales allow you to use multivariate analysis techniques more or less sophisticated as ANOVA, linear regression, logistic regression or discriminant analysis. In small samples, as used in this work, it is possible to use non-parametric statistics such as Mann-Whitney test or the Kolmogorov-Smirnov test.

We are in the first phase of this work, and we understand that there are many challenges in order to improve this tool. Amongst them is the need to improve data collection systems in the science parks, or having the cooperation of all the companies in them installed. Also, the use of metric measurement scales would enable better information processing.

Finally, we considered it interesting to extend the type of variables to be analyzed including variables related to the park itself, besides being able to discriminate between those which can influence the organizations depending if they are EBTs or EBCs.

\section{STRATEGIC IMPLICATIONS FOR THE MANAGEMENT OF SCIENCE PARKS}

Through this proposal, we try to offer an economic and easy to use tool, yet robust and adaptable to the characteristics and needs of science parks. A tool whose main characteristic is to approach and adapt theoretical knowledge developed in the field of business growth to the reality of science parks.

It is a tool that along with others helps in assessment processes, decision-making and management, developed by the park. Thus, it is clear that managers of science parks must consider many of the factors identified and analyzed through this tool. With regard to new projects for university spin-offs, transfer university committees could make a more precise analysis of the viability of the project and the opportunity that is investing in the EBT.

In this regard, we recommend that the university makes a major investment in business projects that are characterized by meeting the factors described above, and, in turn, a minimum investment in those business projects whose analysis does not indicate the expected business growth, but that despite this, the constitution 
of the spin-off or EBT involves removing incompatibilities of researchers and thus the generation of new economic activity and new qualified jobs created.

Also, the above factors are very useful for making decisions about the companies already established in the park. It is essential that the park designs and offers to the companies a service portfolio that suits their characteristics and needs, to promote access to financial resources and a broad network of contacts, to offer opportunities to the entrepreneurs willing to grow. Also, counseling and training, or the possibility of incorporating to the founding team business management experts, will be key in the process of building the company.

Finally, the development of the university and the actions to facilitate the installation of consolidated companies in the park will bring significant benefits in the short, medium and long term. Thus, in the short term, the university will get an additional source to fund the park, while it can create jobs and new knowledge through the development of joint collaboration processes. Along with this, the university provides the basis for the creation of a cluster, which not only acts as an engine of business and local development, but also will have a positive impact on the image and reputation of the university.

\section{REFERENCES}

AERNOUDT, R. Incubators: tool for entrepreneurship? Small Business Economic, Dordrecht, v. 23, n. 2, p. 127-135, Sept. 2004.

AGUADO, R.; CONGREGADO, E.; MILLÁN, J. M. Entrepreneurship financiación e innovación: la situación en la Unión Europea. Economía Industrial, Madrid, n. 347, p. 125-134, 2002.

\section{ASOCIACIÓN DE PARQUES CIENTÍFICOS} Y TECNOLÓGICOS DE ESPAÑA - APTE. [2013]. Available at: < http://www.apte.org/es/>. Access on: 11 Sept. 2013.
ALBAHARI, A.; CATALANO, G.; LANDONI, P. Evaluation of national science park systems: a theoretical framework and its applications to the italian and spanish systems. Technology Analysis and Strategic Management ${ }_{s}$ Abingdon, v. 25, n. 5, p. 599-614, May 2013.

AMASON, A. C.; SAPIENZA, H. J. The effects of top management team size and interaction norms on cognitive and affective conflict. Journal of Management, Thousand Oaks, v. 23, n. 4, p. 495-516, Aug. 1997.

ARDICHVILI, A.; CARDOZO, R.; RAY, S. A theory of entrepreneurial opportunity identification and development. Journal of Business Venturing, Amsterdam, v. 18, n. 1, p. 105-123, Jan. 2003.

BAKOUROS, Y. L.; MARDAS, D. C.; VARSEKELIS, N. C. Science parks, a high tech fantasy?: an analysis of the science parks of Greece. Technovation, [S.1.], v. 22, n. 2, p. 123-128, Feb. 2002.

BASILE, A. Networking system and innovation outputs: the role of science and technology parks. International Journal of Business and Management, Toronto, v. 6, n. 5, p. 3-15, May 2011.

BERAZA-GARMENDIA, J. M.; RODRÍGUEZCASTELLANOS, A. Los programas de apoyo a la creación de spin-offs en las universidades españolas: una comparación internacional. Investigaciones Europeas de Dirección y Economía de la Empresa, Vigo, v. 17, n. 2, p. 89-117, May/August 2011.

BERGEK, A.; NORRMAN, C. Incubators best practices: a framework. Technovation, [S.1.], v. 28, n. 1-2, p. 20-28, Jan./Feb. 2008.

BLINDER, A. S.; MORGAN, J. Are two heads better than one?: an experimental analysis of group vs. individual decision making, Journal of 
Money, Credit and Banking, Columbus, v. 37, n. 5, p. 789-811, Oct. 2005.

BOGLIACINO, F. Innovation and employment: a firm level analysis with European R\&D scoreboard data. IPTS Working Paper on Corporate R\&D and Innovation, Seville, n. 8, Sept. 2010. Available at: <http://iri.jrc.ec.europa. eu/papers/2010_JRC60762_WP8.pdf>. Access on: 11 Sept. 2013.

; PIVA, M.; VIVARELLI, M. R\&D and employment: an application of the LSDVC estimator using european microdata, Economics Letters, Amsterdam, v. 116, n. 1, p. 56-59, July 2012.

BOZEMAN, B.; FAY, D.; SLADE, C. P. Research collaboration in universities and academic entrepreneurship: the-state-of-the-art. The Journal of Technology Transfer, Springer, v. 38, n. 1, p. 1-67, Feb. 2013.

BROWN, J. D.; EARLE, J. S.; LUP, D. What makes small firm grow? Finance, human capital technical assistance, and the business environment in Romania. Economic Development and Cultural Change, Chicago, v. 54, n. 1, p. 33-70, Oct. 2005.

CALVO, J. Testing gibrat's law for small, young and innovating firms. Small Business Economics, Dordrecht, v. 26, n. 2, p. 117-123, Mar. 2006.

CALVO-BABÍO, N. El valor de la gestión del capital intelectual en los parques científicostecnológicos: propuesta de un nuevo modelo organizativo para Galicia. Revista Galega de Economía, Santiago de Compostela, v. 17, n. 2, p. 1-19, dic. 2008.

CHALOS, P.; PICKARD, S. Information choice and cue use: an experiment in group information processing. Journal of Applied Psychology, Washington, D.C., v. 70, n. 4, p. 634-641, Nov. 1985 .
CHANDLER, G. N.; JANSEN, E. The founder's self-assessed competence and venture performance. Journal of Business Venturing, Amsterdam, v. 7, n. 3, p. 223-236, May 1992.

CHETTY, S.; CAMPBELL-HUNT, C. Explosive international growth and problems of success among small to medium-sized firms. International Small Business Journal, London, v. 21, n.1, p. 5-27, Feb. 2003.

CIRIACI, D.; MONCADA-PATERNÒCASTELLO, P.; VOIGT, P. Does size or age of innovative firms affect their growth persistence? Evidence form a panel of innovative Spanish firms. IPTS Working Paper on Corporate R\&D and Innovation, Seville, n. 3, Sept. 2012. Available at: <iri.jrc.ec.europa.eu/papers/WP\%20 3-2012.pdf囚>. Access on: 11 Sept. 2013.

DAVIDSSON, P.; DELMAR, F.; WIKLUND, $J$, Entrepreneurship and the growth of firms. Jönköping: Jönköping International Business School, 2006.

DRUILHE, C.; GARNSEY, E. Do academic spin-out differ and does it matter? The Journal of Technology Transfer, Springer, v. 29, n. 3-4, p. 269-285, Aug. 2004.

EVANS, D. S. Tests of alternative theories of firm growth. Journal of Political Economy, Chicago, v. 95, n. 4, p. 657-674, Aug. 1987.

FARIÑAS, J. C.; MORENO, L. Firms' growth, size and age: a nonparametric approach. The Review of Industrial Organization, Dordrecht, v. 17, n. 3, p. 249-265, Nov. 2000.

FERNÁNDEZ-LÓPEZ, S. et al. Determinantes de la capacidad de las universidades para desarrollar patentes. Revista de la Educación Superior, México, D.F., v. 38, n. 149, p. 7-30, January/March 2009. 
GOWER, S.; HARRIS, F.; COOPER, P. A. Assessing the management of science parks in UK. Property Management, Bradford, v. 14, n. 1, p. 30-38, 1996.

HAMBRICK, D. C.; MASON, P. A. Upper echelons: the organization as a reflection of its top managers. Academy of Management Review, Briarcliff Manor, v. 9, n. 2, p. 193-206, Apr. 1984.

HELLMANN, T.; PURI, M. Venture capital and the professionalization of start-up firms: empirical evidence. The Journal of Finance, Malden, v. 57, n. 1, p. 169-197, Feb. 2002.

INFORMA D\&B. Empresas gacela y empresas de alto crecimiento. 2012. Disponible en: <www. informa.es>. Access on: 11 Sept. 2013.

JORGE-MORENO, J.; GARCÍA-TABUENCA, A.; PABLO MARTÍ, F. Análisis de la relación entre el crecimiento empresarial, la edad de la empresa y la estructura de propiedad. Documento de trabajo de la Universidad de Huelva, Huelva, n. 5, 2003. Available on: <http://www2.uah.es/ iaes/publicaciones/DT_05_03.pdf>. Access on: 10 August 2012.

JO, H.; LEE, J. The relationship between and enterpreneur's background and performance in a new venture. Technovation, [S.1.], v. 16, n. 4, p. 161-171, Apr. 1996.

JOVANOVIC, B. Selection and the evolution of industry. Econometrica, Oxford, v. 50, n. 3, p. 649-670, May 1982.

LAZEAR, E. P. Entrepreneurship. Journal of Labor Economics, Chicago, v. 23, n. 4, p. 649680, 2005.

LEE, D. Y.; TSANG, E. W. K. The effects of entrepreneurial personality, background and network activities on venture growth. Journal of Management Studies, Oxford, v. 38, n. 4, p. 583-602, June 2001.
LEE, C. A theory of firm growth: learning capability, knowledge, threshold, and patterns of growth. Research Policy, [S.1.], v. 39, n. 2, p. 278-289, Mar. 2010.

LOCKETT, A.; WRIGHT, M.; FRANKLIN, S. Technology transfer and universities' spinout strategies. Small Business Economics, Dordrecht, v. 20, n. 3, p. 185-200, Mar. 2003.

LOCKETT, A.; WRIGHT, M. Resources capabilities, risk capital and the creation of university spin-out companies. Research Policy [S.1.], v. 34, n. 7, p.1043-1057, Sept. 2005.

ESPAÑA. Ministerio de La Presidencia. Agencia Estatal Boletín Oficial del Estado. Organic Law, 6/2001, of December 21, of Universities. 2001. Available at: <http://www.boe.es/buscar/act. php?id=BOE-A-2001-24515>. Access on: 11 Sept. 2013.

MARTÍNEZ PAVEZ, C. Análisis conceptual para la gestión de nuevos negocios tecnológicos. In: SEMINARIO-CURSO INTERNACIONAL GESTIÓN DE EMPRESAS TECNOLÓGICAS UNIVERSITARIAS, 2004, Curitiba. [Article abstracts]. Curitiba: Universidad de Sao Paulo, 2004. p. 1-10.

MARTÍNEZ-CAÑAS, R.; SÁEZ-MARTÍNEZ, F.; RUÍZ-PALOMINO, P. La generación de capital social en los parques científicos y tecnológicos: el comportamiento de la empresa ante entornos dinámicos. In: CONGRESO ANUAL, 19. y CONGRESO HISPANO FRANCÉS DE AEDEM, 15., 2007, [S.1.]. [Annals...]. [S.1.: AEDEM], 2007, p. 1-7.

MARTÍNEZ-RODRÍGUEZ, S. Competitividad, innovación y empresas de alto crecimiento en España: identificación de las necesidades de estudio. [Newsletter written for] Dirección General de Política de la Pequeña y Mediana Empresa, Madrid, June 2010. 
MASSEY, D.; QUINTAS, P.; WIELD, D. High tech fantasies: science parks in society, science and space. New York: Routhledge, 1992.

MISHRA, V. Size, age \& firm growth: the computer industry in India. 2004. Available at: <http://unpan1.un.org/intradoc/groups/public/ documents/apcity/unpan023828.pdf>. Access on: 11 Sept. 2013.

MONCADA-PATERNO-CASTELLÓ, P. Companies' growth in the EU: what is research and innovation policy's role? IPTS Working Paper on Corporate R\&D and Innovation, Seville, n. 3, July 2011. Available at: <http://iri. jrc.ec.europa.eu/papers/WP\%2003-2011.pdf>. Access on: 19 January 2013.

NICOLAOU, N.; BIRLEY, S. Academic networks in trichotomous categorisation of university spinouts. Journal of Business Venturing, Amsterdam, v. 18, n. 3, p. 333-359, May 2003.

ONDATEGUI, J. C. Los parques científicos y tecnológicos en España: retos y oportunidades. Madrid: Dirección General de Investigación de la Comunidad de Madrid, 2001.

ORTEGA-ARGILÉS, R.; VIVARELLI, M.; VOIGT, P. R\&D in SMEs: a paradox? Small Business Economics, Dordrecht, v. 33, n. 1, p. 3-11, June 2009.

PARKER, S. C.; PRAAG, C. M. Schooling, capital constraints and entrepreneurial performance: the endogenous triangle. Journal of Business and Economic Statistics, Alexandria, v. 24, n. 4, p. 416-431, Oct. 2006.

The entrepreneur's mode of entry: business takeover or new venture start? Journal of Business Venturing, Amsterdam, v. 27, n. 1, p. 31-46, Jan. 2012.

PARTANEN, J. et al. Social capital in the growth of science-and technology-based SMEs.
Industrial Marketing Management, New York, v. 37, n. 5, p. 513-522, July 2008.

PHAN, P. H.; SIEGEL, D. S.; WRIGHT, M. Science parks and incubators: observations, synthesis and future research. Journal of Business Venturing, Amsterdam, v. 20, n. 2, p. 165-182, Mar. 2005.

PISSARIDES, F.; SINGER, M.; SVEJNAR, J. Objectives and constraints of entrepreneurs: evidence from small and medium-sized enterprises in Russia and Bulgaria. Journal of Comparative Economics, San Diego, v. 31, n. 3, p. 503-531, Sept. 2003.

QUINTAS-CORREDOIRA, M. A. et al. La protección de las invenciones mediante patentes en las universidades europeas, japonesas y estadounidenses. Cuadernos de Gestión, [Bilbao], v. 12, n. 1, p. 15-38, 2012.

RATINHO, T.; HENRIQUES, E. The role of science parks and business incubators in converging countries: evidence from Portugal. Technovation, [S.1.], v. 30, n. 4, p. 278-290, Apr. 2010.

RAUCH, A.; FRESE, M.; UTSCH, A. Effects of human capital and long-term human resources development and utilization on employment growth of small-scale businesses: a causal analysis. Entrepreneurship Theory \& Practice, [S.1.], v. 29, n. 6, p. 681-698, Nov. 2005.

ROBERTS, E. B. Entrepreneurs in high technology: lessons from MIT and Beyond. New York: Oxford University Press, 1991.

RODEIRO-PAZOS, D.; CALVO-BABIO, N. El rol de los parques científico-tecnológicos en el emprendimiento universitario: propuesta de un catálogo de indicadores de evaluación. GCG: Revista de Globalización, Competitividad y Gobernabilidad, [S.1], v. 6, n. 2, p. 95-109, May/ 
August 2012. Available at: <http://gcg.universia. net/pdfs_revistas/articulo_207_1346083145156. pdf>. Access on: 11 Sept. 2013.

SANZ, L. Los parques científicos y tecnológicos: un concepto y una realidad. Encuentros Multidisciplinares, Madrid, v. 13, n. 37, p. 2-9, January/April 2011.

SHANE, S.; STUART, T. E. Organizational endowments and the performance of university start-ups, Management Science, Linthicum, v. 48, n. 1, p. 154-170, Jan. 2002.

SCOTT, J. T.; LINK, A. The growth of research triangle park. Small Business Economics, Dordrecht, v. 20, n. 2, p. 167-175, Mar. 2003.

SUTTER, M. Are four heads better than two? An experimental beauty-contest game with teams of different size. Economics Letters, Amsterdam, v. 88 , n. 1, p. 41-46, July 2005.

TARTARI, V., SALTER, A., D'ESTE, P. Crossing the rubicon: exploring the factors that shape academics perceptions of the barriers of working industry. Cambridge Journal of Economics, Oxford, v. 21, n. 5, p, 1117-1147, 2012.

TEECE, D. J.; PISANO, G.; SHUEN, A. Dynamic capabilities and strategic management.

Strategic Management Journal, Chichester, v. 18, n. 7, p. 509-533, Aug. 1997.

VENDRELL-HERRERO，F.; ORTÍNÁNGEL, P. Evolución comparada de los spinoffs universitarios españoles. CLM. Economía, Toledo, n. 16, p. 345-379, 2010.

VÁSQUEZ-URRIAGO, A. R.; BARGE-GIL, A.; MODREGO RICO, A. Los parques científicos y tecnológicos españoles, impulsores de la cooperación en innovación. ICE: Revista de Economía, n. 869, p. 99-114, Nov./Dec. 2012.
VEDOVELLO, C. Science parks and universityindustry interaction: geographical proximity between the agents as a driving forcé. Technovation, [S.1.], v. 17, n. 9, p. 491-502, Sept. 1997.

VOHORA, A.; WRIGHT, M.; LOCKETT, A. Critical junctures in the development of university high-tech spinout companies. Research Policy, [S.1.], v. 33, n. 1, p. 147-175, Jan. 2004.

WESTHEAD, P.; STOREY, D. J. Links between higher education institutions and high technology firms. Omega International Journal of Management Science, Philadelphia, v. 23, n. 4, p. 345-360, Aug. 1995.

\section{NOTES}

1. University spin-offs are new firms born within the university and driven by academic and research staff as a result of the researches. University Technology Park acts as spin-offs incubator for 3 years. The university spin-offs can be of two types, technology companies (EBT) and knowledge-based company (EBC), based on research results as a basis for the creation of the spin-off (technological or knowledge). In EBTs the result is of a technological nature and can lead to the creation of a patent or the sale of exploitation rights. The EBC is based on the exploitation of the knowledge acquired or generated through research in the field of social sciences and humanities.

2. According to the Law on Science, Technology and Innovation, the university has only the ability to participate in the financial structure of the EBTs. With respect to the EBCs, they have their origin in the university, but present in the park a situation of start-ups created by students or staff from outside the university. So, are embraced in the science park with the intention of undertaking collaborative projects with the university, and promote the recruitment of doctors. In exchange, they can use the services and facilities of the park to a lower economic cost.

3. The contribution of the science park to the new company is relevant. During the first two years of life of the company, access to resources such as management tools, financial support or access to a broad network of contacts are key to the survival of the new company. So, we could say that the portfolio of services offered by the science 
park can facilitate business startup and acceleration of its subsidiaries.

4. Each college has its own power to establish regulations governing the creation of EBT processes and academic spin-offs
5. The Law of Science, Technology and Innovation (LOMLOU) in force in Spain came into force on December 1, 2011. Regarding the role of the university in the transfer process, the law converges with previous Organic Law 4/2007, 